\title{
Contradictions in Frontex Operations: the Push-back
}

\section{Michal VíT ${ }^{1}$ - Gábor KEMÉNY²}

\begin{abstract}
The aim of the paper is to introduce the legal misfits between the standards of human rights as stated by the European Union and the Council of Europe and practical day to day experience related to EU Member States. For this purpose, the article focuses on political and legal assessment of the so-called pushbacks at the Greek-Turkish external border and introduces the influencing factors, such as the various interpretations of the legislation, or differences in the organisational structure and values. The authors conclude that these factors are endangering the fulfilment of the fundamental rights and the efficiency of the border protection, thus the security of the EU and its Member States.
\end{abstract}

Keywords: fundamental rights, police cooperation, border guard, information exchange, push-back, Denmark, Greece, EU law

\section{Introduction}

The issue of protection of the EU's external border has been a matter of extensive focus from politicians, academics and practitioners since the beginning of the migration crisis of 2015 and 2016. These discussions have been dealing mainly with the following issue: how to make the system of border protection more efficient without significant redefinition of institutional structure of cooperation between the European Commission and EU member states? As we argue bellow, this task is very hard to be fulfilled due to growing lack of trust among EU Member States, which makes the EU - in this context the Frontex agency - paralysed in terms of compliance with political motivations and respecting the rule of law of the EU. Analysing the aims of strengthening the capacity of Frontex agency, we identify some weak points that are discussed below. Firstly, EU Member States are increasingly reluctant to respect the EU legal framework when it comes to the border protection, and consequently, operational implications of the Frontex agency. Secondly, there is a question of political and legal implications of the deployment of Frontex outside of the territory of the EU.

Analysing the experience of Frontex from its mission, it shows a complex pattern including security, humanity, and respect to rule of law. In spring 2020 the case of

\footnotetext{
Michal VÍT, PhD, Assistant Professor, Metropolitan University Prague, International Relations and European Studies https://orcid.org/0000-0003-2160-4455; michal.vit@mup.cz

2 Gábor KEMÉNY, dr., pol. ltc., teacher at Law Enforcement Secondary School, Szeged

https://orcid.org/0000-0003-0062-2160; kemeny.gabor@szrszg.hu
} 
the Danish police patrol illustrated the practical impact of blurred responsibility as well as a missing guiding framework. According to Politico.eu, ${ }^{3}$ a Danish patrol refused to follow the order of Greek police not to provide help to migrants who were just attempting to enter the EU on sea. The Greek police requested to push the migrant boat out of EU (Greek) waters, which the Danish patrol refused to do. According to them, such a behaviour has been outside the Frontex mandate and is not in line with EU Fundamental Rights as well as with findings of Fundamental Rights Agency. This very case is only one of many examples where there is a significant mismatch between EU fundamental rights and operational practice in the field. This event shows the significant limits in protecting the EU's external border five years after the emergence of the migration crisis in 2015 and 2016. As discussed by many experts, such as Sergio Carrera, ${ }^{4}$ there is a divergence between the rule of law set by the EU and the Council of Europe enforced by EU institutions and agencies, and the security measures introduced and implemented by EU Member States.

Of similar perspectives of questionable efficiency and legitimacy of the EU's external border protection is the case of the Croatian-Bosnian border. ${ }^{5}$ Bosnia and Herzegovina - particularly Una-Sana Canton - has become an attractive spot in 2018 due to the need to find new means of getting to the EU, and the fragile political situation in Bosnia served as an excuse to avoid direct institutional and political responsibility. Croatia is not a member of the Schengen area and therefore Croatia is responsible for the system of border between Croatia and Bosnia. Coordination with other EU member states and the European Commission is based primarily on exchange of information on the number of illegal entries of third country nationals and asylum seekers, and/or the number of returns. However, Croatia aims to become part of the Schengen area most likely in 2020. ${ }^{6}$ This decision is of purely political nature, since it requires agreement of all EU Member States when it comes to voting at the Council of the EU. That said, the membership is a result of political bargaining in which Croatia needs to be perceived as able to provide effective protection of the EU's external border. In this context, Croatian authorities acknowledged the existence of push-back to Bosnian territory without adequate registration and cooperation with Bosnian colleagues. ${ }^{7}$

3 Laurie Tritschler, 'Danish boat in Aegean refused order to push back rescued migrants', Politico, 06. 03. 2020. Available: www.politico.eu/article/danish-frontex-boat-refused-order-to-push-back-rescued-migrants-report/ (25. 11. 2020.)

4 Sergio Carrera, 'The EU Border Management Strategy: FRONTEX and the Challenges of Irregular Immigration in the Canary Islands', CEPS Working Document, no. 261, 2007.

5 Michal Vít and Gábor Kemény, 'External EU Border Protection: who is doing what?' Heinrich Böll Stiftung, Sarajevo, 2019. Available: https://ba.boell.org/en/2019/11/21/external-eu-border-protection-who-doing-what (25. 11. 2020.)

6 'Croatia ready to join border-free Schengen area, EU Commission says', Reuters, 22. 10. 2019. Available: www.reuters.com/article/us-croatia-eu-schengen/croatia-ready-to-join-border-free-schengen-area-eu-commission-saysidUSKBN1X11R1 (25. 11. 2020.)

7 Srdjan Govedarica, 'Vermisst, vergessen, unbeachtet', ARD-Current / Tagesschau.de, 25. 03. 2019. Available: www. tagesschau.de/ausland/balkanroute-141.html (25. 11. 2020.); 'Desperate journeys: Refugee and migrant children arriving in Europe and how to strengthen their protection', UNHCR - United Nations High Commissioner for Refugees, 2019. Available: https://data2.unhcr.org/en/documents/download/71703Uni (25. 11. 2020.) 


\subsection{EU versus Member States}

This shows that the relationship between the EU and its Member States was influenced by the migration crisis mostly as a result of two factors. The first is the regular business, which includes dealing with the migrants flows by providing housing, health and legal assistance. The second one is the assistance provided to national authorities within EU and non-EU countries on the field of border management. Although capable control of the external borders has become an important topic for both the EU and its Member States since the outbreak of the migration crisis in 2015, the realisation of an efficient border management has been blocked by the conflicting aims of the European Commission and the EU Member States. At the same time, the area of border protection remained the competence of the Member States, where the European Commission can only play a coordinative role. ${ }^{8}$

This again highlighted the intergovernmental nature of the Schengen cooperation, which generates a complex institutional and political structure on the field of external border protection. This structure lets the Member States to act according to their national interest instead of coordinated EU policies. The main challenge during the implementation of the Schengen Borders Code comes from the intergovernmental nature of border management. The Code does not regulate the cooperation with third countries, which is an essential element of the efficient border protection. For this reason, cooperation with non-EU countries mostly depends on the political will of the neighbouring countries, which is articulated in the bilateral agreements. These agreements are outside of the legal framework of the EU by nature and therefore result in a limited control and transparency on behalf of the EU. ${ }^{9}$

\section{Legal aspects}

This opens the very important issue of analysing impacts of migration crisis in the Balkans. Namely, what are the side effects of tough border regime on Schengen and EU border? Since asylum seekers have only limited prospect to get to their destination legally and since there is only limited interest to apply EU coordinated asylum and migration policy, it creates tension alongside the EU external border. As a result, representatives of law enforcement agencies of individual Member States do not experience a coordinated approach by EU authorities as they are practitioners of the EU's dysfunctional policy coordination. Said that, the main problem is thus a very vaguely defined cooperation among EU and national authorities towards external border protection. It is a result of non-existing integrated and enforced EU border protection regime that would provide comprehensive approach also towards asylum and migration policies. Since there is no

\footnotetext{
'Vít and Kemény, 'External EU Border Protection'.

Gábor Kemény, 'The present and the future of cross border police and customs information exchange between the EU and the Western Balkan region', Public Security and Public Order 20 (2018), 126.
} 
possibility to enforce EU regulation by the Court of Justice of the European Union, the jurisdiction remains in full responsibility of the Member States. The EU's main legal regulation, the Schengen Borders Code, ${ }^{10}$ is part of the legislation of all EU member states as a harmonised legislation without supranational control of the Court of Justice of the EU. Therefore, it implies that EU Member States will follow the similar track of practice when applying international regulations for the protection of refugees and persons requesting international protection. ${ }^{11}$ Thus, it opens space for extensive politisation of the border management issues. This is illustrated by the case ' $M$. H. versus Croatia' dealing with the incident on the Serbian-Croatian border in November 2017. The Croatian authorities have refused to investigate the case of a girl deadly hit by train on Croatian territory and pushed back the family to Serbia without any legal and health assistance. The turbulent situation is a result of lacking transparent legal and political framework when it comes to communicating of EU priorities. Considering that we are speaking about countries that want to join EU and about external borders of the EU, this generates consequences for the rule of law in the region as well as the image of the EU as such. This practice has been matter of attention of the Parliamentary Assembly of the Council of Europe stating the following:

'As these practices are widespread, and in some countries systematic, these "pushbacks « can be considered as part of national policies rather than incidental actions. The highest risk attached to pushbacks is the risk of refoulement, meaning that a person is sent back to a place where they might face persecution in the sense of the 1951 United Nations Convention Relating to the Status of Refugees, ${ }^{12}$ or inhuman or degrading treatment in the sense of the European Convention on Human Rights. ${ }^{13}$

Based on the above, one can identify these challenges when it comes to lack of consistency between operational practice and EU/international legal framework. There is a significant lack of strategy from the EU when it comes to harmonisation of operational practice with the Charter of Fundamental Rights of the EU. However, according to the Lisbon Treaty, neither the European Commission nor the Court of Justice of the EU has the competence to enforce the Charter of Fundamental Rights. Given the nature of the Area of Freedom, Security, and Justice, the EU lacks law enforcement mechanism in this policy area. This means that the European Court on Human Rights (ECHR), being outside the EU's standing structure, has no legal - and political - jurisdiction. Only EU Member States are included in the ECHR's jurisdiction. Nevertheless, the enforcement of the court's decision only relies on the political will of the state. Going back to the operational practice of Frontex, this blurred environment is defined as follows.

10 Regulation (EC) No 562/2006 of the European Parliament and of the Council of 15 March 2006 establishing a Community Code on the rules governing the movement of persons across borders (Schengen Borders Code). Official Journal of the European Union. Available: https://eur-lex.europa.eu/legal-content/EN/TXT/HTML/?uri=CELEX:32006R0562\&from=HU (25. 11. 2020.), Art. 3.

11 Carrera, 'The EU Border Management Strategy'.

12 The Refugee Convention, 1951. United Nations. Available: www.unhcr.org/4ca34be29.pdf (25. 11. 2020.)

13 'Pushback policies and practice in Council of Europe member States (Resolution 2299/2019)', Parliamentary Assembly, 2019. Available: http://assembly.coe.int/nw/xml/XRef/Xref-XML2HTML-EN.asp?fileid=28074 (25. 11. 2020.), Para 1. 
'In case of violations of human rights or international protection obligations that are serious or likely to persist, the agency's Executive Director should suspend or terminate such operations', in line with Article 46 of the Frontex regulation. ${ }^{14}$ However, this is in sharp contrast with the practice on the EU's external border as well as with the legal and political lessons learned from 2015 and 2016 when the migration flows reached its peak. ${ }^{15}$ As the numerous evidences of push-backs show, it is extremely difficult to enforce international human rights regulations even if our EU institutions openly address the requested modus operandi. It is a clear evidence of strong political influence over law enforcement that is at the same time without clear jurisdiction on the EU level (with regard to fundamental rights.)

\section{Operational aspects}

As it was detailed above, border management is a shared responsibility of Frontex and the Member States. ${ }^{16}$ This shared responsibility means that the primary responsibility of managing the external borders lies with the Member States, while the agency is supporting the efforts of the national authorities by facilitating the application of the EU's border management measures. Frontex currently provides this support mainly by seconded team members from the Member States. These officers have a 'dual responsibility', they are responsible both to their home organisation and to Frontex during the operations, and they also work under the command and control of the hosting country. ${ }^{17}$

As a novelty, the creation of a 'standing corps' under the new Frontex regulation is also ongoing. Contrary to the previously described responsibility system, this creates a new situation. The statutory and long-term seconded staff will be responsible only towards Frontex, while the system of dual responsibility remains during the deployment of the short-term seconded staff and the reserve for rapid reaction. ${ }^{18}$

\section{Implications for Frontex}

Such events and the strengthening role of Frontex raises serious concerns about how the current border management system is prepared to cope with fundamental legal challenges. Given the rigidity of political process concerning the reform of primary law of the EU, it shall be clarified whether this intensified border protection gives more

\footnotetext{
14 Regulation (EU) 2019/1896 of the European Parliament and of the Cuncil of 13 November 2019 on the European Border and Coast Guard. Official Journal of the European Union. Available: https://eur-lex.europa.eu/legal-content/EN/ TXT/HTML/?uri=CELEX:32019R1896\&from=HU (25. 11. 2020.)

15 Mikael Cederbratt, 'Frontex: human rights responsibilities', Parliamentary Assembly, 2013. Available: https://assembly.coe.int/nw/xml/XRef/Xref-XML2HTML-en.asp?fileid=19547\&lang=en (25.11. 2020.)

16 Regulation (EU) 2019/1896, 1.

17 'Vít and Kemény, 'External EU Border Protection'.

18 Ibid.
} 
power to Member States and weakens the position of EU institutions. If the answer is yes, the current legal framework of Frontex is hardly sustainable. Referring to the above mentioned Danish incident, decision makers and operational staff shall pay attention to the mandate of Frontex and of its missions. This implies that Frontex operations must be in harmony with fundamental rights, as is it interpreted by EU institutions and agencies. Therefore, the Frontex is in a schizophrenic position of defending two EU interests: the emerging need to provide security, or to respect rule of law. The Danish case draws attention to the significant gap between what Frontex and seconded officers shall do, and how it is supposed to be implemented. The official statement of the agency ${ }^{19}$ and the Frontex regulation, ${ }^{20}$ which emphasise the importance of respecting fundamental rights, does not really influence the situation on the field. ${ }^{21}$

Beside the previously described political and legal dimensions, the border management has also an operational dimension, which derives from the fact that Frontex is composed as an intergovernmental organisation as it mostly operates with the resources of Member States. Coming from this, Frontex has only limited capacity and resources to implement security measures in line with the Charter of Fundamental Rights ${ }^{22}$ of the EU. ${ }^{23}$

Acknowledging the legitimacy of this statement the concerns are raised in relation to the deployed staff who has dual responsibility and accountability described in the previous section. While these police officers work under the limited command and control of Frontex, they have been heavily influenced by the organisational culture and values of their sending country, which has an impact on their attitude towards respect for fundamental rights. As we learnt from the Danish case, the measures that Danish officers considered to be a clear violation of the fundamental rights were executed by the police officers coming from other Member States. The authors argue that this phenomenon will not disappear with the creation of the 'standing corps', as still only a small number of the deployed staff will have sole responsibility towards Frontex, while the other officers will act and operate under the structure of dual responsibility and accountability. ${ }^{24}$

\section{Operation outside EU territory}

Frontex operations outside the EU raise even more fundamental questions about legality and efficiency. Frontex shall present and protect EU norms, legislation and values in a territory where the legal framework is only vaguely harmonised with the EU standards and best practices. This means that Frontex is given a political mandate

\footnotetext{
9 Ska Keller, 'New rules on Frontex operations at sea'. LIBE Special, April 2014. Available: www.statewatch.org/ news/2014/apr/ep-green-keler-mep-frontex-operations-at-sea.pdf (25. 11. 2020.)

20 Regulation (EU) 2019/1896, para 80.

1 'Vít and Kemény, 'External EU Border Protection'.

22 Charter of fundamental rights of the European Union (2000/C 364/01), Official Journal of the European Communities, 2000. Available: www.europarl.europa.eu/charter/pdf/text_en.pdf (25. 11. 2020.)

23 'Vít and Kemény, 'External EU Border Protection'.

24 Ibid.
} 
that is impossible to be implemented, as Frontex assistance missions - for instance in the Western Balkans - would be conducted in a certain legal vacuum. ${ }^{25}$ This sends very blurred message towards the Frontex missions. The question may arise as a legitimate one: The operation in third country is an EU capacity building instrument, which provides efficient and needed assistance for the border police services, or rather the instrument of Member States in order to have their 'agents on spots' when fulfilling the mission?

\section{Conclusions}

Various interpretations of the fundamental rights and legislation, differences in organisational culture and values result in different and contradictory police measures in the border area. In this context, a further nationalising of Frontex's institutional culture is the most probable result of similar events. It means that, hand in hand with growing incidents like in February/March 2020 on the Greek-Turkish border causing an increased number of people aiming to enter the EU irregularly, the Frontex agency will experience further tensions on both institutional and operational level mostly coming from the different organisational culture. This significantly jeopardises the functionality and the success of the operations, the security of the EU and its Member States, and therefore may question the need for further EU support from the requesting country. As stated above, since Member States and their cooperation is crucial for border protection, the role of the agency being an EU agency might be questioned in terms of moving responsibility as well as power to Member States.

\section{REFERENCES}

Carrera, Sergio: 'The EU Border Management Strategy: FRONTEX and the Challenges of Irregular Immigration in the Canary Islands'. CEPS Working Document, no. 261, 2007. DOI: https://doi. org/10.2139/ssrn.1338019.

Cederbratt, Mikael: 'Frontex: human rights responsibilities'. Parliamentary Assembly, 2013. Available: https://assembly.coe.int/nw/xml/XRef/Xref-XML2HTML-en.asp?fileid=19547\&lang=en (25. 11. 2020.)

Charter of fundamental rights of the European Union (2000/C 364/01). Official Journal of the European Communities, 2000. Available: www.europarl.europa.eu/charter/pdf/text_en.pdf (25. 11. 2020.)

'Croatia ready to join border-free Schengen area, EU Commission says'. Reuters, 22. 10. 2019. Available: www.reuters.com/article/us-croatia-eu-schengen/croatia-ready-to-join-border-free-schengenarea-eu-commission-says-idUSKBN1X11R1 (25.11. 2020.)

Govedarica, Srdjan: 'Vermisst, vergessen, unbeachtet'. ARD-Current / Tagesschau.de, 25. 03. 2019. Available: www.tagesschau.de/ausland/balkanroute-141.html (25.11. 2020.)

\footnotetext{
25 Ismail Kamberi, 'Tackling the Migrant Crisis in the Republic of North Macedonia', European Policy Institute - Skopje, 2019. Available: https://epi.org.mk/wp-content/uploads/2020/02/Tackling-the-Migrant-Crisis.pdf (25. 11. 2020.)
} 
Kamberi, Ismail: 'Tackling the Migrant Crisis in the Republic of North Macedonia'. European Policy Institute - Skopje, 2019. Available: https://epi.org.mk/wp-content/uploads/2020/02/ Tackling-the-Migrant-Crisis.pdf (25. 11. 2020.)

Keller, Ska: 'New rules on Frontex operations at sea'. LIBE Special, April 2014. Available: www.statewatch. org/news/2014/apr/ep-green-keler-mep-frontex-operations-at-sea.pdf (25. 11. 2020.)

Kemény, Gábor: 'The present and the future of cross border police and customs information exchange between the EU and the Western Balkan region'. Public Security and Public Order 20 (2018), 117-133. DOI: https://doi.org/10.6084/m9.figshare.12100710.v1

'Pushback policies and practice in Council of Europe member States (Resolution 2299/2019)', Parliamentary Assembly, 2019. Available: http://assembly.coe.int/nw/xml/XRef/ Xref-XML2HTML-EN.asp?fileid=28074 (25. 11. 2020.)

Regulation (EC) No 562/2006 of the European Parliament and of the Council of 15 March 2006 establishing a Community Code on the rules governing the movement of persons across borders (Schengen Borders Code). Official Journal of the European Union. Available: https://eur-lex. europa.eu/legal-content/EN/TXT/HTML/?uri=CELEX:32006R0562\&from=HU (25. 11. 2020.)

Regulation (EU) 2019/1896 of the European Parliament and of the Cuncil of 13 November 2019 on the European Border and Coast Guard. Official Journal of the European Union. Available: https://eur-lex. europa.eu/legal-content/EN/TXT/HTML/?uri=CELEX:32019R1896\&from=HU (25. 11. 2020.)

The Refugee Convention, 1951. United Nations. Available: www.unhcr.org/4ca34be29.pdf (25.11. 2020.)

Tritschler, Laurie: 'Danish boat in Aegean refused order to push back rescued migrants'. Politico, 06. 03. 2020. Available: www.politico.eu/article/danish-frontex-boat-refused-order-to-pushback-rescued-migrants-report/ (25. 11. 2020.)

Vít, Michal - Kemény, Gábor: 'External EU Border Protection: who is doing what?' Heinrich Böll Stiftung, Sarajevo, 2019. Available: https://ba.boell.org/en/2019/11/21/ external-eu-border-protection-who-doing-what (25.11. 2020.)

\section{ABSZTRAKT}

\section{Ellentmondások a Frontex múveletekben: a push-back (Visszaszorítás)}

Michal VÍT- KEMÉNY Gábor

A tanulmány célja az Európai Unió és az Európa Tanács által deklarált alapjogok és normák alkalmazása során felmerülő visszásságok bemutatása. A cikk ezt a görög-török határon foganatosított visszaszorítást (push-back) lehetővé tevő és megakadályozó tényezők, így az eltérő jogértelmezés, szervezeti kultúra és értékrendek bemutatásán keresztül kívánja elérni. A cikk szerzői arra a következtetésre jutottak, hogy a fenti tényezők jelentősen veszélyeztetik az alapvető emberi jogok érvényesülését, valamint negatívan befolyásolják a határigazgatás eredményességét és ezáltal az EU és tagállamai biztonságát.

Kulcsszavak: alapjogok, rendőrségi együttműködés, határőrség, információcsere, Dánia, Görögország, EU-jog 